\title{
DIALECTAL DIFFERENCES IN VOICING ASSIMILATION PATTERNS: THE CASE OF MORAVIAN CZECH ENGLISH
}

\author{
PAVEL ŠTURM and LEA TYLEČKOVÁ
}

\begin{abstract}
One challenge for the second language (L2) learner of English is to master a novel phonetic implementation of the voicing contrast, whereas another challenge is to learn how consonant sequences behave in connected speech. Learners of English coming from three different language backgrounds were tested; their native varieties were Bohemian Czech, Moravian Czech, and Slovak. The Moravian variety of Czech is more similar in voicing assimilation to the Slovak language than to the Bohemian variety of Czech. Percentage of phonetic voicing was measured in the L2 (i.e. English) word-final obstruents preceding three classes of sounds: voiceless and voiced obstruents, and sonorants. Bohemian and Moravian speakers exhibited different strategies in pre-sonorant contexts, following their native (variety-specific) assimilation rules.
\end{abstract}

Key words: voicing assimilation, transfer, Czech, dialect, L2 English

\section{Introduction}

As a prime example of a phonological process with clear phonetic grounding, assimilation is a frequent pattern recurring in many languages (Gordon, 2016: Chapter 5). Speakers tend to produce articulatory gestures with some degree of overlap, which may result in segmental changes and elisions. Assimilation can thus be viewed as adaptation of speech sounds to the immediate contex - one sound modifies some of its characteristics, so that the result is more similar to the conditioning segment. The influence is usually anticipatory/regressive (Farnetani \& Recasens, 2010). For instance, the place of articulation of the nasal consonant in the Spanish indefinite article "un" is pronounced differently when preceding labial, dental, alveolar or velar consonants ([um'baso] "a glass", [uñ 'deðָo] "a finger", [un'layo ] "a lake", [un'gato] "a cat”). In this case, the assimilation occurs online between words in connected speech, but it can also be lexicalized, as in the English prefixed word "impolite" /, Impə'lait/. However, the focus of assimilation is not restricted to the consonantal place dimension; we frequently encounter assimilation of voicing (both within words and between words) or, less frequently, manner of articulation. Sounds can even undergo complete assimilation, i.e., modification of all their features, creating articulatory geminates (e.g., the past participle Finnish suffix /nut/, in which the $/ \mathrm{n} /$ becomes identical to the preceding oral continuant sound; Gordon, 2016: 
125). Given the extensive use of assimilation in the world's languages and, more to the point, the natural tendency of speakers to simplify their production at various levels (Lindblom, 1983), it is not surprising that assimilation is readily transferred to a second language (Altenberg \& Vago, 1983; Cebrian, 2000; Simon, 2010), creating high potential for L1 and L2 interaction.

The current article investigates the assimilation of voicing in L2 learners of English with various native languages and varieties. Although voicing assimilation is relevant in the English language for some morphemes (like the plural or the past tense), voicing changes across the word boundary are not allowed. For instance, "lake" is pronounced with a phonologically voiceless obstruent at the end irrespective of the following segment (/lêIk pəôt/, /lêIk ba:d/). In other words, the assimilated form /lêg ba:d/ is not to be expected. ${ }^{1}$ In contrast, many Slavic languages do assimilate voicing across words extensively. In Czech, one would say /dost pejes/ "enough money", but /dozd bodu:/ "enough points" (for voicing assimilation rules in Czech, see e.g. Palková, 1994: 329ff.). Consequently, voicing of the final obstruent in these languages can entirely be predicted based on the following context, the voicing distinction being neutralized, whereas in English, the distinction is maintained, albeit through other acoustic correlates than actual phonetic voicing (see Chen, 1970; Blevins, 2006).

Interestingly, the Czech language is not uniform in terms of voicing assimilation across the word boundary (see e.g. Palková, 1994: 329ff.), which is similar, for instance, to Polish, whose dialects may be classified into "voicing" and "devoicing" based on assimilatory activity before sonorants (Lew, 2002). There are two main varieties of Czech: Bohemian and Moravian (see Šimáčková, Podlipský \& Chládková, 2012). In Moravian Czech, voicing is also assimilated before sonorants, giving rise to forms like /dozd masa/ "enough meat", which would be considered non-standard in Bohemian Czech (where /dost masa/ is pronounced). Thus, Moravian Czech patterns with Slovak in this respect (Pauliny, 1979: 152ff.; Bárkányi \& Beňuš, 2015; Bárkányi \& Kiss, 2015).

It is clear from the facts mentioned above that the assimilatory process is highly language- and even variety-specific, and therefore prone to interaction in L2 acquisition when the two languages have different assimilation systems. Restricting our attention to L2 English, we can point out several studies that all showed evidence of transferring L1 assimilation rules into L2 English production (Altenberg \& Vago, 1983 for Hungarian; Rubach, 1984 and Lew, 2002 for Polish; Cebrian, 2000 for Catalan; Simon, 2010 for Dutch). In these studies, voiceless targets were typically realized as voiced when preceding voiced obstruents. Word-final voicing has also been studied in Czech English. The implementation of the voicing contrast was examined by Fejlová (2013) or by Skarnitzl and Šturm (2016), whereas the process of voicing assimilation itself was analysed by Skarnitzl and Poesová (2008), Kanioková (2011) and Skarnitzl and Šturm (2014, 2017). The latter work (Skarnitzl \& Šturm, 2017) focused on voicing assimilation in L1 British English and in the L2 speech of Czech and Slovak speakers. An interesting finding was that whereas the two L2 groups showed comparable patterns before obstruents, the

1 Traditional works on English phonetics (e.g. Cruttenden, 2014) do not admit cross-word assimilation, especially if a voiceless segment should become voiced. However, empirical data suggest that the situation is more complex. For example, Jansen $(2004,2007)$ found that word-initial [d] and [z] exerted some influence on the voicing of word-final [k] in native British English. 
context before sonorant consonants yielded disparate patterns: the (Bohemian) Czech participants tended to produce voiceless pre-sonorant obstruents (at [t] least), but the Slovak speakers had a tendency to assimilate voicing to the following sonorant segment, producing a voiced sound (at [d] least). Crucially, this reflected the voicing assimilation rules of the respective L1 languages, which differ in the pre-sonorant context.

Importantly, Chládková and Podlipský (2011) showed that learning L2 speech sounds contrasts is not only language-specific, but also variety-specific. They examined the cross-language perception of Dutch vowels by speakers of the Bohemian and Moravian varieties of Czech. Their study revealed different perceptual assimilation patterns in the non-native Dutch high front vowel region that reflected the between-dialect acoustic differences in signalling the L1 Czech phonological length contrast in high front vowels.

In the present study, we investigate whether Bohemian and Moravian speakers exhibit variety-specific voicing assimilation patterns in L2 English. We can hypothesize that they will behave in a variety- rather than language-specific manner. If this is the case, then, Moravian Czech L2 English should be closer to Slovak L2 English (a different source language, but with similar assimilation rules) than to Bohemian Czech English (the same source language, but with dissimilar assimilation rules). A second research question will be connected to the general pronunciation competence of our L2 speakers, which might also influence the strength of L1-L2 transfer. We predict that more accented speakers will show higher rates of voicing assimilation in L2 English than less accented speakers.

\section{Method}

The current study presents new data but also uses acoustic data from our previous study (Skarnitzl \& Šturm, 2017). The "new" dataset involves speakers of Moravian Czech L2 English (MorCZ), whereas the "previous" dataset was based on speakers of Bohemian Czech L2 English (BohCZ) and Slovak L2 English (SK), in addition to a control British English (BrE) L1 group not considered here. The recording and analysis were identical in both cases. To facilitate statistical comparisons between the groups, both datasets are merged into a single analysis.

\subsection{Participants}

12 female speakers of Moravian Czech were recorded with origin in various Moravian and Silesian regions, i.e., regions where pre-sonorant voicing assimilation occurs. Auditory observation of their productions confirmed that their Czech production had the "assimilating" characteristics typical of the Moravian variety of Czech. In contrast, the 12 Bohemian Czech speakers from the previous dataset did not show this type of voicing assimilation in their Czech production. The Slovak group also included 12 speakers. All the speakers were female and aged between 20 and 25 years.

The three learner groups comprised two types of speakers. Six speakers belonged to a "more-accented (ma)" group with a strong Czech/Slovak accent in their English and six to a "less-accented (la)" group that was almost near-native in their pronunciation of English. In the previous study, the speakers were selected from a larger corpus of L2 
English based on agreement between three phoneticians. In addition, the speakers were evaluated by seven native speakers of English in terms of foreign accent strength on a 7-point scale. The results showed a clear separation between the "ma" and "la" groups; the control group (BrE) was evaluated similarly as the "la" group, but with a clear separation from the "ma" group.

For the current study, we recorded 6 Moravian Czech students of English philology in Prague whose pronunciation was considered near-native ("la"). For the "ma" group, three speakers were recorded in Prague immediately at the start of their English studies, and three more speakers who did not study English at all were recorded in Olomouc. Both groups were characterized by a strong Czech accent. Nevertheless, a perceptual evaluation was also conducted to substantiate the categorization of the Moravian speakers' accent strength into "ma" and "la" groups. 56 listeners (students of English studies, aged 18-68, with mean age 21.18 and sd 7.1) were asked to evaluate the speakers' foreign accent strength on a 7-point scale ranging from "strong foreign accent" (1) to "nativelike" (7). The test included the 12 MorCZ speakers, 12 SK speakers and also 6 native speakers of English as controls and several L2 speakers of other languages as fillers. The listeners were assigned one of four test versions differing in presentation order, and evaluated 60 stimuli. The duration of the test was 11 minutes.

The results did not show significant differences between the four test versions (differing in trial orders). Figure 1 shows the evaluation of the speakers' accent strength as a function of learner group. There was a clear difference between the "ma" and "la" groups of both Moravian and Slovak speakers. The mean value of the "la" participants differed somewhat from the control native English group (Tukey contrasts: MorCZ by -0.96 with $\mathrm{SE}=0.3, z=-3.1, p<0.05$; SK by -1.09 with SE $=0.3, z=-3.5, p<0.01$ ), whereas the "ma" participants differed substantially (MorCZ by -3.68 with SE $=0.3, z=-11.7, p<$ 0.001 ; SK by -3.88 with $\mathrm{SE}=0.3, z=-12.4, p<0.001$ ). We can therefore conclude that our initial evaluation of the MorCZ speakers was correct.

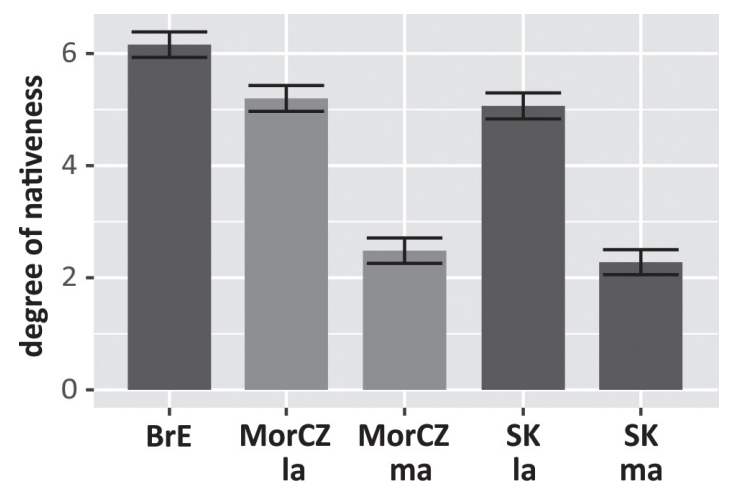

Figure 1. Evaluation of foreign accent strength (degree of nativeness) for an L1 British English (BrE) control group and for L2 groups of more ("ma") and less accented ("la") Moravian Czech (MorCZ) and Slovak (SK) speakers. For Bohemian Czech speakers, see Skarnitzl and Šturm (2017). 


\subsection{Material}

After sufficient time for preparation, the participants were asked to read one of six BBC World Service news bulletins. In the MorCZ group, "ma" and "la" speakers were matched for the text version. They were recorded in sound-treated studios in Prague and Olomouc (16-bit, $32 \mathrm{kHz}$.wav files recorded with a condenser microphone). Each recording was approximately 4 minutes long and consisted of 450-500 words, depending on the text version. The speakers from Skarnitzl and Šturm (2017) were recorded in the Prague studio under the same conditions but, due to the corpus structure, the text versions were not matched between the "la" and "ma" groups, and a wider range of texts was used as well (16 versions).

The recordings were automatically segmented by means of P2FA forced alignment (Yuan \& Lieberman, 2008), and the boundaries of the target speech sounds were manually adjusted based on the phonetically motivated recommendations for manual segmentation of the speech signal (Machač \& Skarnitzl, 2009). The targets involved two consecutive phones - a word-final obstruent and the initial consonant of the following word (except for $/ \mathrm{h} /$ ). Therefore, there were three contexts in which the target sound occurred: before a voiceless (fortis) consonant, before a voiced (lenis) consonant, and before a sonorant consonant. The nature of the preceding speech sound was not controlled. Target sequences interrupted with a pause were excluded since we do not expect assimilation to occur in such cases. The presence of prosodic breaks was noted, as the assimilation rate may differ within and across prosodic boundaries (Mády \& Bárkányi, 2015). The analysis was based on 947 tokens (MorCZ data) and 1952 tokens (SK and BohCZ data from Skarnitzl \& Šturm, 2017). The structure of the data is shown in Table 1.

Table 1. Breakdown of the dataset according to learner group (Bohemian Czech, Moravian Czech, Slovak, $\mathrm{la}=$ less accented, $\mathrm{ma}=$ more accented $)$ and assimilatory context $(\mathrm{vl}=$ voiceless, $\mathrm{vd}=$ voiced, son $=$ sonorant $)$.

\begin{tabular}{lccccccc}
\hline Learner group & vl-vl & vd-vl & vl-vd & vd-vd & vl-son & vd-son & Group total \\
\hline BohCZ_la & 59 & 123 & 55 & 123 & 66 & 83 & $\mathbf{5 0 9}$ \\
BohCZ_ma & 58 & 127 & 42 & 127 & 85 & 60 & 499 \\
MorCZ_la & 57 & 118 & 67 & 109 & 74 & 76 & $\mathbf{5 0 1}$ \\
MorCZ_ma & 32 & 104 & 61 & 115 & 62 & 72 & $\mathbf{4 4 6}$ \\
SK_la & 101 & 110 & 57 & 120 & 73 & 60 & $\mathbf{5 2 1}$ \\
SK_ma & 99 & 66 & 50 & 91 & 60 & 57 & $\mathbf{4 2 3}$ \\
\hline Assim. context total & 406 & 648 & 332 & 685 & 420 & 408 & 2899 \\
\hline
\end{tabular}

\subsection{Analysis}

In order to assess voicing of the target sounds, we examined the presence or absence of the fundamental frequency (F0), which was extracted in all word-final obstruents in Praat (Boersma \& Weenink, 2017) with the default setting for F0 extraction, as we were not interested in specific values. The degree of voicing was expressed as the percentage of 
voicing. Voicing information was extracted every millisecond and the voicing ratio was computed for each target sound (i.e., how much of the consonant was produced with vocal fold vibration).

For statistical analysis we used the publicly available program R (R Core Team, 2019) and the associated R packages lme4, effects and ggplot2 (Bates, Mächler, Bolker, \& Walker, 2015; Fox, 2003; Wickham, 2009). Linear mixed-effects (LME) modelling was chosen because it is suitable for multiple observations from the same speaker or of the same item to resolve the non-independence of such observations. The fixed effects were AssimILATORY CONTEXT $(\mathrm{vl}-\mathrm{vl} \times \mathrm{vl}$-vd $\times$ vl-son $\times$ vd-vl $\times$ vd-vd $\times$ vd-son), LEARNER GROUP $($ BohCZ_la $\times$ BohCZ_ma $\times$ MorCZ_la $\times$ MorCZ_ma $\times$ SK_la $\times$ SK_ma), ProsodiC BREAK $($ yes $\times$ no), TARGET MANNER (fricative $\times$ stop) and LEXICAL STATUs (lexical $\times$ grammatical). The random effects were the intercepts for SUBJECT and wORD; by-subject random slopes were not added because the complex effect structure would lead to singularity in the random terms. Whether individual fixed effects/interactions were significant was evaluated by comparing the full model to a reduced model in which the factor in question was excluded, using likelihood ratio tests. In addition, pairwise comparisons were evaluated post hoc using Tukey contrasts from the multcomp package (Hothorn, Bretz \& Westfall, 2008).

\section{Results and discussion}

Skarnitzl and Šturm (2017) reported some general phonetic and linguistic effects on voicing assimilations of Czech and Slovak learners of English. For instance, the presence of a prosodic break after the target obstruent led to a decrease in the amount of phonetic voicing, or word-final fricatives were on the whole articulated with less voicing than word-final stop consonants. We therefore included such factors in the current model by default and examined their interactions. Prosodic BREAK interacted with LEXICAL STATUS $\left(\chi^{2}(1)=6.9, p<0.01\right)$ : grammatical words were associated with a higher degree of voicing than lexical words, but only in the absence of a prosodic break. Furthermore, the LEXICAL STATUS effect was restricted to stop consonants, as fricatives did not show any difference in voicing between lexical and grammatical words $\left(\chi^{2}(1)=4.4, p<0.05\right)$. Finally, there was no significant interaction between PROSODIC BREAK and TARGET MAN$\operatorname{NER}\left(\chi^{2}(1)=0.01, p=0.89\right)$.

The factors of greatest interest for the present research question are Assimilatory CONTEXT and LEARNER GROUP. Crucially, there was a significant interaction between them $\left(\chi^{2}(25)=255.6, p<0.001\right)$. The fixed effects estimates of the full model are given in Appendix A, but it is easier to evaluate the direction and size of the effects in the accompanying effects plots in Figure 2. The contexts before word-initial voiceless consonants (Fig. 2a) are included as baselines for determining the degree of phonetic voicing due to carryover from previous sounds. The results generally follow the expectations that there should be no significant differences between the varieties, given that all L1 backgrounds assimilate in these contexts. However, the less accented BohCZ speakers yielded a higher rate of voicing in the lenis-fortis (voiced-voiceless) context compared to the other groups, which might reflect a more English-like pronunciation (i.e., an attempt at approximation 
to word-final devoicing, rather than to assimilation). Also, there was a general tendency in all groups to produce more phonetic voicing in the lenis targets compared to the fortis targets.

With regard to the pre-sonorant contexts (Fig. 2b), several aspects need to be mentioned. Although the BohCZ speakers did not assimilate word-final voiceless consonants before sonorants, treating the target sounds as if a voiceless consonant followed (compare the solid columns in Fig. 2b to 2a), the MorCZ group was associated with a significantly higher amount of phonetic voicing before sonorants. Consequently, the MorCZ variety resembled more closely the Slovak group, which was likewise associated with a higher amount of voicing in this context but which manifested additional differences in speaker accentedness. Finally, we can also examine the performance of individual learner groups within the given context. Crucially, the more accented MorCZ speakers differed significantly from the corresponding BohCZ speakers but not from the corresponding SK speakers. In contrast, there were no significant differences among the varieties in the less accented speakers. The results of post hoc multiple comparisons using Tukey contrasts are provided in Appendix B.

However, the patterns become more complex when the word-initial sonorant consonant is preceded by a lenis (phonologically voiced) consonant (transparent colours in Fig. $2 \mathrm{~b}$ and Tukey post-hoc tests in Appendix B). On the one hand, an analogous effec - a shift towards significantly higher voicing percentages before sonorants - was associated with the MorCZ and SK speakers. On the other hand, it was also found in the less accented BohCZ group, which does not seem to follow the expectations. Even so, we suggest that it is not a clear argument for assimilation, as discussed by Skarnitzl and Šturm (2017). Whereas the more accented BohCZ speakers produced a low amount of voicing before sonorants, identical to the pre-voiceless contexts, the less accented BohCZ speakers might have been targeting the devoiced word-final lenis obstruent in native English by maintaining phonetic voicing. This would make them seemingly pattern with the "assimilating" groups, but it could in fact reflect their higher awareness that word-final voicing is not neutralized in English, and an attempt to aim for such a target. It is thus difficult to say what the finding about MorCZ speakers in the voiced-sonorant context means: is the higher amount of phonetic voicing due to L1 transfer, or to a higher pronunciation proficiency level, as suggested for the BohCZ less accented speakers?

Results from the contexts before word-initial voiced consonants (Fig. 2c) indicate, first, that there is a significant increase in each learner group in the amount of voicing compared to the contexts before voiceless consonants. Moreover, with the exception of the less accented SK speakers, all groups yielded a higher percentage of voicing before voiced sounds than before sonorants. This, of course, clearly reflects the L1 assimilation rules, although it needs to be explained why the percentages are not higher, approaching 100\% (at least for the more accented speakers). Second, the voiced targets again yielded higher rates of assimilation in comparison to the voiceless targets. Finally, the more accented speakers of each variety were more prone to assimilation than the less accented speakers, although the effect size differed for individual varieties.

Interestingly, there is a recurring pattern in the data regarding the more accented speakers: Slovaks were associated with a higher amount of phonetic voicing than MorCZ speakers, and these in turn with more phonetic voicing than BohCZ speakers. The lan- 

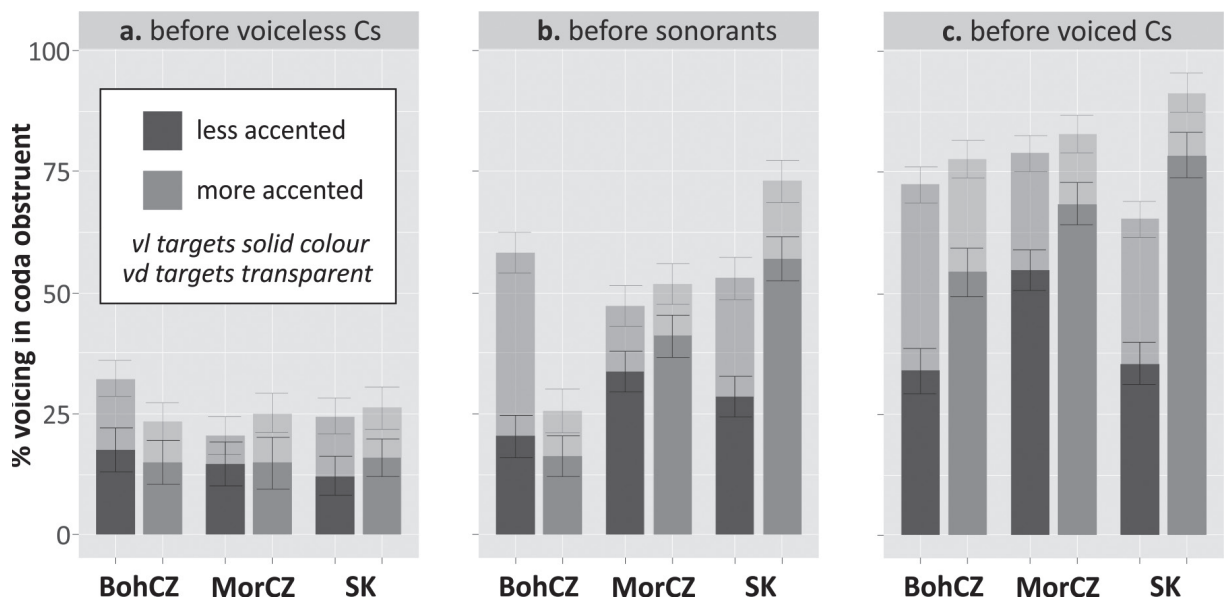

Figure 2. Mean amount of phonetic voicing (\% of the target sound duration) in different assimilatory contexts and different learner groups $(\mathrm{BohCZ}=$ Bohemian Czech, MorCZ = Moravian Czech, SK = Slovak, vl = voiceless, $\mathrm{vd}=$ voiced). Effect plots from an LME analysis.

guage background provides a possible explanation: Bohemian Czech assimilates obstruents before other obstruents, Moravian Czech before obstruents and sonorants, and Slovak before obstruents, sonorants and also vowels. The speakers might be differentially primed from their native systems in their L2 English production, triggering different rates of transfer. Another pattern is apparent in Figure 2 if we examine the contexts which are arguably most conclusive about transfer, i.e., voiceless targets before voiced and sonorant consonants. The higher degree of assimilation in the less accented Moravian Czech speakers suggests they are less advanced L2 users than the corresponding "la" Slovaks (and Bohemian Czechs), despite being judged similarly in the perception test. Indeed, the accentedness effect sizes are greater for the latter group than for Moravian Czechs.

\section{General discussion}

The objective of the study was to investigate whether voicing assimilation strategies in Moravian Czech English tend to be more similar to Bohemian Czech English or to Slovak English, taking into account the speakers' pronunciation competence in English. We observed differences between less and more accented speakers, the effect being most pronounced in the Slovak speakers. One could argue that the degree of accentedness, although treated identically in the three $\mathrm{L} 2$ varieties (i.e., as a binary variable), was in fact not comparable, and that, for instance, the Slovaks showed a higher degree of phonetic voicing because of a generally higher degree of accentedness. However, the results of the perceptual tests (see Fig. 1 and Skarnitzl \& Šturm, 2017) indicate that this was not the case, given that all members of the more vs. less accented groups received similar scores irrespective of their dialect. Nevertheless, it could still be the case that the tendency to 
assimilate is not necessarily correlated with the evaluation of the speakers' foreign accent strength, as it was based on overall pronunciation skills and not on assimilatory behaviour. In other words, a speaker who behaves in terms of assimilation entirely according to the L2 rules might still be perceived as heavily-accented, and vice versa.

Our results showed a clear evidence of L1 interference in the English language production in all the three groups, especially with regard to the more accented speakers. On the one hand, all three L2 English groups of speakers produced word-final obstruents with substantial phonetic voicing before phonologically voiced consonants, whereas in the contexts before initial voiceless consonants, the target sounds were associated with a low degree of phonetic voicing. This finding can be interpreted as a transfer of L1 assimilation rules into an L2, which is manifested identically in the different varieties. On the other hand, the pre-sonorant contexts were associated with different assimilation strategies in the two varieties of Czech - the Moravian Czech speakers approximated the Slovak speakers, exhibiting assimilatory behaviour to a greater extent than did the Bohemian Czech speakers (but to a smaller extent than did the Slovaks). Moravian Czech English thus seems to be in this respect intermediate between Bohemian Czech and Slovak English. Moreover, we can conclude based on the effect sizes that Moravian Czech English is closer to Slovak English, a different source language that nevertheless has similar assimilation rules, than to Bohemian Czech English, the same source language but with different assimilation rules. There was even a statistically significant difference from the Bohemian Czech group if we consider the more accented speakers. In any case, the finding suggests that the two varieties of Czech exhibit L2 English assimilatory behaviour in a dissimilar way, and the direction of the effect is influenced by the assimilation rules of the speakers' own, variety-specific phonological system. These findings are in line with Lew's results for Polish dialects (Lew, 2002).

One aspect of our data is particularly interesting. In all the groups and regardless of the type of the word-initial consonant, word-final phonologically voiced sounds were associated with a generally higher degree of voicing than the corresponding voiceless counterparts (compare the transparent and solid colours in Fig. 2). Why is it so? The most probable explanation is that speakers are aware - not necessarily consciously - of the fact that, in native English, word-final /d z/ etc. do not turn into /t s/ (unlike in Czech or Slovak). This would be supported by the differential behaviour of the more and less accented speakers. The less accented speakers, who might be hypothesized to be more proficient and more aware of the L2 phonological system, seem to show greater differences between underlying voiced vs. voiceless target consonants compared to the more accented speakers (see Fig. 2). This would correspond to the findings of Cebrian (2000), where such positive transfer (i.e., /d/ realized with phonetic voicing before a voiced sound) was stronger than negative transfer (/t/ realized with phonetic voicing before a voiced sound).

Future research might further examine L2 voicing assimilation patterns by applying a more refined control of the assimilatory contexts, taking into account the voicing status of the preceding sounds as well. Apart from that, it would also be useful to measure vowel duration, which is an important cue to phonological voicing in native English (Chen, 1970; Jansen, 2004; Davidson, 2016). This approach might help differentiate between assimilation per se, when the phonological voicing status is changed, and obstruent devoicing, when the underlying category remains the same despite changes in phonetic 
voicing. Moreover, it would then be clearer whether the presence of phonetic voicing in word-final obstruents in L2 English reflects the transfer of L1 voicing assimilation patterns, or a higher level of pronunciation proficiency in Bohemian, Moravian, and Slovak speakers of English. Finally, in addition to measuring the percentage of voicing in the target word-final obstruents, the voicing profile method (Möbius, 2004) could be applied to capture the dynamics of voicing, which may provide a more detailed insight into individual assimilatory contexts.

\section{ACKNOWLEDGEMENTS}

The work was supported by the European Regional Development Fund-Project 'Creativity and Adaptability as Conditions of the Success of Europe in an Interrelated World' (No. CZ.02.1.01/0.0/0.0/16_019/0000734). The second author was supported from the project 'Language and its research tools', solved at Charles University from Specific university research in 2018.

\section{REFERENCES}

Altenberg, E. \& Vago, R. (1983). Theoretical implications of an error analysis of second language phonology production. Language Learning, 33(4), 427-447.

Bárkányi, Z. \& Beňuš, Š. (2015). Prosodic conditioning of pre-sonorant voicing. Proceedings of the 18th ICPhS. Retrieved from https://www.internationalphoneticassociation.org/icphspproeedings /ICPhS2015/Papers/ICPHS0336.pdf

Bárkányi, Z. \& Kiss, Z. G. (2015). Why do sonorants not voice in Hungarian? And why do they voice in Slovak? In: K. É. Kiss, B. Surányi \& É. Dékány (Eds.), Approaches to Hungarian: Volume 14: Papers from the 2013 Piliscsaba conference (pp. 65-94). Amsterdam: John Benjamins Publishing Company.

Bates, D., Mächler, M., Bolker, B., \& Walker, S. (2015). Fitting linear mixed-effects models using lme4. Journal of Statistical Software, 67(1), 1-48.

Blevins, J. (2006). A theoretical synopsis of Evolutionary Phonology. Theoretical Linguistics, 32(2), 117-166.

Boersma, P. \& Weenink, D. (2017). Praat: doing phonetics by computer (version 6.0.36) [Computer software]. Retrieved from http://www.praat.org.

Cebrian, J. (2000). Transferability and productivity of L1 rules in Catalan-English interlanguage. Studies in Second Language Acquisition, 22(1), 1-26.

Chen, M. (1970). Vowel length variation as a function of the voicing of the consonant environment. Phonetica, 22(3), 129-159.

Chládková, K. \& Podlipský, V.J. (2011). Native dialect matters: Perceptual assimilation of Dutch vowels by Czech listeners. Journal of the Acoustical Society of America, 130, EL186-192.

Cruttenden, A. (2014). Gimson's Pronunciation of English (Eighth Edition). London: Routledge.

Davidson, L. (2016). Variability in the implementation of voicing in American English obstruents. Journal of Phonetics, 54(1), 35-50.

Farnetani, E. \& Recasens, D. (2010). Coarticulation and connected speech processes. In: W. J. Hardcastle, J. Laver \& F. Gibbon (Eds.), The Handbook of Phonetic Sciences (2nd edition) (pp. 316-352). Oxford: Wiley-Blackwell.

Fejlová, D. (2013). Pre-fortis shortening in fluent read speech: A comparison of Czech and native speakers of English. AUC Philologica 1/2014, Phonetica Pragensia XIII, 91-100.

Fox, J. (2003). Effect displays in R for generalised linear models. Journal of Statistical Software, 8(15), $1-27$. 
Gordon, M. K. (2016). Phonological Typology. Oxford: Oxford University Press.

Hothorn, T., Bretz, F. \& Westfall, P. (2008). Simultaneous inference in general parametric models. Biometrical Journal, 50(3), 346-363.

Jansen, W. (2004). Laryngeal contrast and phonetic voicing: A laboratory phonology approach to English, Hungarian, and Dutch. PhD Thesis. University of Groningen, The Netherlands.

Jansen, W. (2007). Phonological 'voicing', phonetic voicing, and assimilation in English. Language Sciences, 29(2), 270-293.

Kanioková, Z. (2011). Voicing assimilation in English spoken by Czech and Slovak learners. BA thesis.

Lew, R. (2002). Differences in the scope of obstruent voicing assimilation in learners' English as a consequence of regional varieties in Polish. In: E. Waniek-Klimczak \& P. James Melia (Eds.), Accents and Speech in Teaching English Phonetics and Phonology: EFL Perspective (pp. 243-264). Frankfurt am Main: Peter Lang.

Lindblom, B. (1983). Economy of speech gestures. In: P. F. MacNeilage (Ed.), The Production of Speech (pp. 217-246). Berlin: Springer.

Machač, P. \& Skarnitzl, R. (2009). Principles of Phonetic Segmentation. Prague: Epocha.

Mády, K., \& Bárkányi, Z. (2015). Voicing assimilation at accentual phrase boundaries in Hungarian. Proceedings of the 18th ICPhS. Retrieved from https://www.internationalphoneticassociation.org /icphsproceedings/ICPhS2015/Papers/ICPHS0796.pdf.

Möbius, B. (2004). Corpus-based investigations on the phonetics of consonant voicing. Folia Linguistica, $38,5-26$.

Palková, Z. (1994). Fonetika a fonologie češtiny [Phonetics and phonology of Czech]. Prague: Karolinum.

Pauliny, E. (1979). Slovenská fonológia [Slovak phonology]. Bratislava: Slovenské pedagogické nakladatel'stvo.

R Core Team (2019). R: A language and environment for statistical computing (version 3.5.3) [Computer software]. R Foundation for Statistical Computing, Vienna. Retrieved from http://www.R-project.org.

Rubach, J. (1984). Rule typology and phonological interference. In: S. Eliasson (Ed.), Theoretical issues in contrastive phonology: Studies in descriptive linguistics (pp. 37-50). Heidelberg: Julius Groos.

Simon, E. (2010). Phonological transfer of voicing and devoicing rules: Evidence from L1 Dutch and L2 English conversational speech. Language Sciences, 32(1), 63-86.

Skarnitzl, R. \& Poesová, K. (2008). Typology of voicing changes in Czech English. In: A. Grmelová, L. Dušková, M. Farrell \& R. Pípalová (Eds.), Plurality and Diversity in English Studies - Proceedings from the Third Prague Conference on Linguistics and Literary Studies (pp. 8-17). Prague: Faculty of Education, Charles University in Prague.

Skarnitzl, R. \& Šturm, P. (2014). Assimilation of voicing in Czech speakers of English: The effect of the degree of accentedness. Research in Language, 12, 199-208.

Skarnitzl, R. \& Šturm, P. (2016). Pre-fortis shortening in Czech English: A production and reaction-time study. Research in Language, 14, 1-14.

Skarnitzl, R. \& Šturm, P. (2017). Voicing assimilation in Czech and Slovak speakers of English: Interactions of segmental context, language and strength of foreign accent. Language and Speech, 60(3), 427-453.

Šimáčková, Š., Podlipský, V., \& Chládková, K. (2012). Czech spoken in Bohemia and Moravia. Journal of the International Phonetic Association, 42(2), 225-232.

Wickham, H. (2009). ggplot2: Elegant graphics for data analysis. New York: Springer.

Yuan, J. \& Liberman, M. (2008). Speaker identification on the SCOTUS corpus. Proceedings of Acoustics '08. Retrieved from http://www.ling.upenn.edu/ jiahong/publications/c09.pdf. 


\section{APPENDIX A}

Regression coefficients of fixed effects in the LME model $(\mathrm{vl}=$ voiceless, $\mathrm{vd}=$ voiced, son $=$ sonorant, $\mathrm{BohCZ}=$ Bohemian Czech, MorCZ = Moravian Czech, SK = Slovak, la = less accented, $\mathrm{ma}=$ more accented). The intercept corresponds to fricatives in grammatical words in the vl-vl context spoken by less accented BohCZ speakers when no prosodic boundary was present.

\begin{tabular}{|c|c|c|c|}
\hline Fixed effect & Estimate & SE & t-value \\
\hline Intercept & 17.31 & 5.16 & 3.36 \\
\hline ASSIMILATORY CONTEXT (vl-vd) & 16.35 & 4.90 & 3.33 \\
\hline ASSIMILATORY CONTEXT (vl-son) & 2.74 & 4.64 & 0.59 \\
\hline ASSIMILATORY CONTEXT (vd-vl) & 14.63 & 4.21 & 3.48 \\
\hline ASSIMILATORY CONTEXT (vd-vd) & 54.82 & 4.22 & 12.99 \\
\hline ASSIMILATORY CONTEXT (vd-son) & 40.72 & 4.49 & 9.08 \\
\hline LEARNER GROUP (BohCZ_ma) & -2.71 & 6.23 & -0.44 \\
\hline LEARNER GROUP (MorCZ_la) & -3.05 & 6.16 & -0.50 \\
\hline LEARNER GROUP (MorCZ_ma) & -2.74 & 6.81 & -0.40 \\
\hline LEARNER GROUP (SK_la) & -5.38 & 5.84 & -0.92 \\
\hline LEARNER GROUP (SK_ma) & -1.65 & 5.78 & -0.29 \\
\hline PROSODIC BREAK (yes) & -28.02 & 5.14 & -5.45 \\
\hline LEXICAL STATUS (lexical) & -4.37 & 2.86 & -1.53 \\
\hline TARGET MANNER (stop) & 17.91 & 3.91 & 4.58 \\
\hline CONTEXT (vl-vd) : GROUP (BohCZ_ma) & 23.15 & 7.13 & 3.25 \\
\hline CONTEXT (vl-son) : GROUP (BohCZ_ma) & -1.32 & 6.35 & -0.21 \\
\hline CONTEXT (vd-vl) : GROUP (BohCZ_ma) & -6.07 & 5.72 & -1.06 \\
\hline CONTEXT (vd-vd) : GROUP (BohCZ_ma) & 8.07 & 5.70 & 1.42 \\
\hline CONTEXT (vd-son) : GROUP (BohCZ_ma) & -29.97 & 6.37 & -4.70 \\
\hline CONTEXT (vl-vd) : GROUP (MorCZ_la) & 23.89 & 6.50 & 3.68 \\
\hline CONTEXT (vl-son) : GROUP (MorCZ_la) & 16.56 & 6.28 & 2.64 \\
\hline CONTEXT (vd-vl) : GROUP (MorCZ_la) & -8.75 & 5.63 & -1.56 \\
\hline CONTEXT (vd-vd) : GROUP (MorCZ_la) & 9.51 & 5.66 & 1.68 \\
\hline CONTEXT (vd-son) : GROUP (MorCZ_la) & -7.93 & 6.07 & -1.31 \\
\hline CONTEXT (vl-vd) : GROUP (MorCZ_ma) & 37.3 & 7.17 & 5.20 \\
\hline CONTEXT (vl-son) : GROUP (MorCZ_ma) & 23.49 & 7.04 & 3.34 \\
\hline CONTEXT (vd-vl) : GROUP (MorCZ_ma) & -4.33 & 6.39 & -0.68 \\
\hline CONTEXT (vd-vd) : GROUP (MorCZ_ma) & 13.28 & 6.34 & 2.09 \\
\hline CONTEXT (vd-son) : GROUP (MorCZ_ma) & -3.88 & 6.75 & -0.57 \\
\hline CONTEXT (vl-vd) : GROUP (SK_la) & 6.92 & 6.41 & 1.08 \\
\hline CONTEXT (vl-son) : GROUP (SK_la) & 13.53 & 6.02 & 2.25 \\
\hline
\end{tabular}




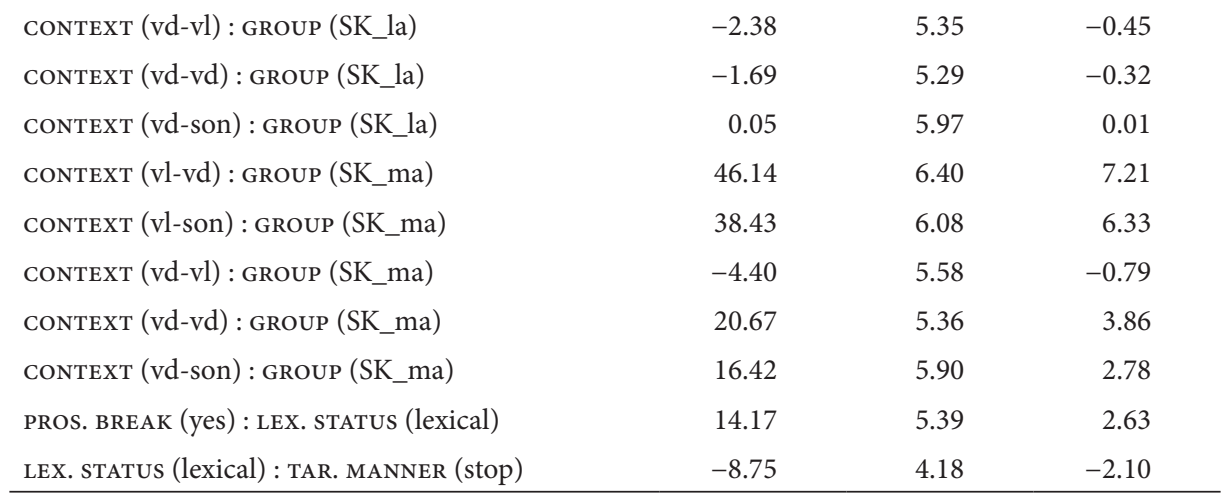

\section{APPENDIX B}

Tukey multiple comparisons of means (only selected contrasts of interest). Positive estimates indicate that the first member in the comparison was associated with higher proportions of voicing in the word-final obstruent $(\mathrm{BohCZ}=$ Bohemian Czech, MorCZ $=$ Moravian Czech, $\mathrm{SK}=$ Slovak, $\mathrm{la}=$ less accented, $\mathrm{ma}=$ more accented, $\mathrm{vl}=$ voiceless, $\mathrm{vd}=$ voiced, son $=$ sonorant $)$.

Table B.1: Effect of CONTEXT.

\begin{tabular}{lccccc}
\hline Learner group & Pairwise comparison & Estimate & SE & $\boldsymbol{z}$ & adjusted $\boldsymbol{p}$ \\
\hline BohCZ_la & vl-son - vl-vl & 2.74 & 4.64 & 0.59 & 1.00 \\
BohCZ_ma & vl-son - vl-vl & 1.42 & 4.43 & 0.32 & 1.00 \\
MorCZ_la & vl-son - vl-vl & 19.30 & 4.49 & 4.30 & $<0.01$ \\
MorCZ_ma & vl-son - vl-vl & 26.23 & 5.46 & 4.80 & $<0.001$ \\
SK_la & vl-son - vl-vl & 16.27 & 3.94 & 4.14 & $<0.05$ \\
SK_ma & vl-son - vl-vl & 41.17 & 4.22 & 9.76 & $<0.001$ \\
\hline BohCZ_la & vd-son - vd-vl & 26.09 & 3.55 & 7.34 & $<0.001$ \\
BohCZ_ma & vd-son - vd-vl & 2.19 & 3.90 & 0.56 & 1.00 \\
MorCZ_la & vd-son - vd-vl & 26.92 & 3.61 & 7.46 & $<0.001$ \\
MorCZ_ma & vd-son - vd-vl & 26.55 & 3.77 & 7.05 & $<0.001$ \\
SK_la & vd-son - vd-vl & 28.52 & 3.98 & 7.17 & $<0.001$ \\
SK_ma & vd-son - vd-vl & 46.91 & 4.49 & 10.46 & $<0.001$ \\
\hline
\end{tabular}


Table B.2: Effect of LEARNER GROUP.

\begin{tabular}{llcccc}
\hline Context & Pairwise comparison & Estimate & SE & $z$ & adjusted $\boldsymbol{p}$ \\
\hline vl-son & MorCZ_la - BohCZ_la & 13.51 & 5.83 & 2.32 & 0.90 \\
vl-son & MorCZ_la - SK_la & 5.36 & 5.74 & 0.93 & 1.00 \\
vl-son & BohCZ_la - SK_la & -8.15 & 5.90 & -1.38 & 1.00 \\
vl-son & MorCZ_ma - BohCZ_ma & 24.78 & 5.75 & 4.31 & $<0.01$ \\
vl-son & MorCZ_ma - SK_ma & -16.04 & 6.03 & -2.67 & 0.68 \\
vl-son & BohCZ_ma - SK_ma & -40.81 & 5.85 & -6.98 & $<0.001$ \\
\hline vd-son & MorCZ_la- BohCZ_la & -10.98 & 5.60 & 1.96 & 0.99 \\
vd-son & MorCZ_la-SK_la & -5.65 & 5.83 & 0.97 & 1.00 \\
vd-son & BohCZ_la - SK_la & 5.33 & 5.82 & 0.92 & 1.00 \\
vd-son & MorCZ_ma - BohCZ_ma & 26.06 & 5.85 & 4.45 & $<0.01$ \\
vd-son & MorCZ_ma - SK_ma & -21.38 & 5.91 & -3.62 & 0.08 \\
vd-son & BohCZ_ma - SK_ma & -47.45 & 6.08 & -7.81 & $<0.001$ \\
\hline
\end{tabular}

Table B.3: Effect of ACCENTEDNESS.

\begin{tabular}{lllcccc}
\hline Context & Variety & Pairwise comparison & Estimate & SE & $\boldsymbol{z}$ & adjusted $\boldsymbol{p}$ \\
\hline vl-son & BohCZ & ma - la & -4.04 & 5.83 & -0.69 & 1.00 \\
vl-son & MorCZ & ma - la & 7.23 & 5.78 & 1.25 & 1.00 \\
vl-son & SK & ma - la & 28.63 & 5.94 & 4.82 & $<0.001$ \\
\hline vd-son & BohCZ & ma - la & -32.68 & 5.84 & -5.59 & $<0.001$ \\
vd-son & MorCZ & ma - la & 4.36 & 5.62 & 0.78 & 1.00 \\
vd-son & SK & ma - la & 20.09 & 6.07 & 3.31 & 0.20 \\
\hline
\end{tabular}




\title{
RESUMÉ
}

Osvojování znělostního kontrastu a jeho fonetická realizace představuje u nerodilých mluvčích angličtiny nelehký úkol, zejména, jedná-li se o konsonantické shluky v souvislé řeči. Tato studie se zaměřuje na asimilaci znělosti anglických finálních obstruentů u mluvčích pocházejících ze tří různých jazykových oblastí - Čech, Moravy a Slovenska. Jelikož moravští mluvčí uplatňují asimilaci znělosti podobně jako slovenští mluvčí, a naopak rozdílně než mluvčí obecné češtiny, lze předpokládat, že osvojování cizího jazyka bude ovlivněno nejen jazykově specifickými charakteristikami, ale rovněž odlišnostmi mezi varietami téhož jazyka. Autoři studie sledují míru fonetické znělosti (kvantifikovanou jako podíl trvání znělé části cílového konsonantu) při produkci čteného anglického textu. Cílový segment se nacházel $\mathrm{v}$ pozici před třemi typy iniciálních konsonantů: před neznělými a znělými obstruenty a před sonorami. Výsledky analýz potvrzují, že se mluvčí z Čech a Moravy řídí v kontextech před sonorami odlišnými strategiemi, což odpovídá asimilačním pravidlům z rodné variety jazyka. Anglický čtený projev mluvčích z Moravy se tak blíží z hlediska asimilací spiše mluvčím ze Slovenska než mluvčím z Čech.

\author{
Pavel Šturm and Lea Tylečková \\ Institute of Phonetics \\ Faculty of Arts, Charles University \\ Prague, Czech Republic \\ E-mail: pavel.sturm@ff.cuni.cz
}

